\title{
Genomic DNA extraction from small amounts of serum to be used for $\alpha_{1}$-antitrypsin genotype analysis
}

\author{
S. Andolfatto*, F. Namour*, A-L. Garnier*, F. Chabot*, J-L. Gueant*, I. Aimone-Gastin*
}

Genomic DNA extraction from small amounts of serum to be used for $\alpha_{1}$-antitrypsin genotype analysis. S. Andolfatto, F. Namour, A-L. Garnier, F. Chabot, J-L. Gueant, I. Aimone-Gastin. (C) ERS Journals Ltd 2003.

ABSTRACT: If laboratory diagnosis of $\alpha_{1}$-antitrypsin $\left(\alpha_{1}-\mathrm{AT}\right)$ deficiency is usually based on its phenotype identification by isoelectric focusing, $\alpha_{1}$-antiprotease inhibitor (Pi)S and PiZ genotypes can also be determined by deoxyribonucleic acid (DNA)-based methods. Recently, several methods have been described for preparing genomic DNA from serum. The aim of the current study was to determine the $\mathrm{Pi}$ allele from serum extracted DNA by polymerase chain reaction (PCR) and to compare these results with those obtained with whole blood extracted DNA.

Serum $\alpha_{1}$-AT concentration and phenotypic identification were systematically performed in 43 hospitalised patients. Genomic DNA was simultaneously purified from whole blood and from serum. The mutation detection was found using a PCRmediated site-directed mutagenesis method.

Concerning phenotypic identification, 29 patients were MM homozygotes, 11 were heterozygotes for $\mathrm{S}(\mathrm{MS}=7)$ or for $\mathrm{Z}(\mathrm{MZ}=4)$ and three showed a $\mathrm{ZZ}$ phenotype. Genotyping analyses gave identical results with serum and whole blood extracted DNA and all the results were in agreement with the phenotyping results.

The authors found that the deoxyribonucleic acid-based test proved to be a reliable tool for $\alpha_{1}$-antitrypsin deficiency diagnosis and appears to be an alternative for the labour intensive $\alpha_{1}$-antitrypsin determination by isoelectric focusing. The authors also concluded that this method yields good quality deoxyribonucleic acid from serum, equal to that extracted from whole blood and is helpful in retrospective studies of multiple genetic markers.

Eur Respir J 2003; 21: 215-219.
*Laboratory of Proteins Biochemistry and "Respiratory Diseases Dept, University Hospital of Nancy-Brabois, Nancy, France.

Correspondence: I. Aimone-Gastin Laboratory of Proteins Biochemistry University Hospital of Nancy-Brabois C.H.U. de Nancy-Brabois

Rue du Morvan

54511 Vandoeuvre Les Nancy

France

Fax: 33183153591

E-mail: i.gastin@chu-nancy.fr

\section{Keywords: $\alpha 1$-antitrypsin}

genomic deoxyribonucleic acid extraction genotype

phenotype

polymerase chain reaction

serum

Received: May 232002

Accepted after revision: August 262002
The $\alpha_{1}$-antiprotease inhibitor (Pi), or $\alpha_{1}$-antitrypsin $\left(\alpha_{1}-\mathrm{AT}\right)$, is the principal serum inhibitor of lysosomal proteases, such as neutrophil elastase [1]. The $\alpha 1-A T$ is a polymorphic single chain glycoprotein of $52 \mathrm{kDa}$ and 394 amino acids, synthesised in the liver and normally present in serum at $150-350 \mathrm{mg} \cdot \mathrm{dL}^{-1}$ [2]. It displays $>90$ different genetically determined phenotypes [3]: phenotype $M$ is the normal variant ( $90 \%$ of the population) and phenotypes $\mathrm{S}$ and $\mathrm{Z}$ are the two most frequent abnormal variants [3]. Calculated values of PI ZZ prevalence are approximately: 1:1,000-1:145,000 in Western and Northern Europe; 1:45,000-1:10,000 in Central Europe; and 1:10,000-1:90,000 in Eastern Europe and in the southernmost and northernmost areas of the continent. In the white population of USA, Canada, Australian and New Zealand, PI ZZ phenotype prevalence ranges from 1:2,000-1:7,000 individuals. In nonwhite populations $\alpha_{1}$-AT deficiency is thought to be a rare or nonexistent disease $[4,5]$. Homozygosity for the $\mathrm{Z}$ phenotype is the principal cause of $\alpha_{1}$-AT deficiency. It typically leads to the development of diverse liver diseases in children and adults and to early adult onset emphysema, with plasma level of $\alpha_{1}$-AT in homozygous PiZ individuals reaching only $10-15 \%$ of $\alpha_{1}$-AT concentration observed in PiM individuals [6, 7]. Although individuals MS or SS are unaffected, SZ subjects may be symptomatic. More recently, $\alpha_{1}$-AT deficiency has been associated with asthma, bronchiectasis, vasculitis and panniculitis $[8,9]$.

The $\alpha_{1}$-AT gene comprises seven exons dispersed over $12 \mathrm{~kb}$ of the chromosomal segment $14 \mathrm{q} 31-32.3$ and is expressed in hepatocytes and mononuclear phagocytes [2]. The mutation in the PiZ allele consists of a single base substitution (guanine to adenine) in exon $\mathrm{V}$, which results in a change at amino acid 342 (from glutamic acid (GLU) to lysine) [10]. The PiS allele is characterised by the substitution of adenine with thymine, in exon III, which results in the amino acid valine at position 264 instead of GLU [11].

Laboratory tests are absolutely necessary for diagnosis of $\alpha_{1}$-AT deficiency. Routinely, this diagnosis is based on the measurement of serum $\alpha_{1}$-AT concentration and the identification of $\alpha$ l-AT phenotype by isoelectric focusing (IEF). IEF sometimes presents equivocal results or discordances compared with serum $\alpha_{1}$-AT measurements [2, 12, 13]. Since several years, $\mathrm{PiS}$ and PiZ genotypes can also be determined by deoxyribonucleic acid (DNA)-based methods [2, 13, 14, 15]. 
DNA in plasma or serum was first discovered in 1948 by Mandel and Metais [16]. Although it is now evident that DNA circulates freely in blood plasma both in health and in disease, the source of this DNA remains enigmatic. It is presumed that circulating DNA in healthy subjects is derived from lymphocytes or other nucleated cells [17]. Recently, several methods have been described for preparing genomic DNA from serum with some of them requiring very small amounts of serum ranging from $20-250 \mu \mathrm{L}$ [18-21]. These microextraction procedures allow DNA to be obtained and be used as a template to amplify DNA segments as large as 3,789 base pairs (bp). The amplified polymerase chain reaction (PCR) products are of similar quality than that of DNA prepared from whole blood specimens [19]. The aim of this study was to extract DNA from serum, to determine the Pi allele by the PCR-mediated site-directed mutagenesis previously described [22] and to compare these results with those obtained with control DNA extracted from peripheral blood cells.

\section{Methods}

\section{Patients}

From March-December 2001, a total of 43 venous blood samples were collected from patients who were hospitalised in the Universitary Hospital of Nancy (18 female and 25 male; mean age $52.2 \pm 22.6$ yrs (mean \pm SD), range $0.5-90 \mathrm{yrs}$ ). A total of 11 patients were hospitalised in the Respiratory Diseases Department and were known to suffer from a pulmonary emphysema $(n=10)$ or a chronic bronchitis $(n=1)$. A total of three of these patients were already diagnosed and were $\mathrm{ZZ}$ homozygotes.

\section{Quantitative determination of $\alpha_{1}$-antitrypsin concentration}

The $\alpha_{1}$-AT measurement was performed in serum samples using a rate immune nephelometric method (Immage Immuno-Chemistry System, Beckman-Coulter, Roissy, France). The immune nephelometer automatically dilutes samples 1:36 to achieve optimum antigenantibody equilibrium in the assay.

\section{$\alpha_{1}$-antitrypsin phenotyping}

Identification of the phenotype was systematically carried out on $3 \mu \mathrm{L}$ of each serum sample by use of an IEF technique on flat bed polyacrylamide gels in a $\mathrm{pH}$ gradient of 4.2-4.9 (Phast gel dry IEF; Pharmacia, Uppsala, Sweden), as the major variants $\mathrm{M}, \mathrm{S}$, and Z focus between $\mathrm{pH} 4.5$ and 4.7 [23]. After Coomassie R 350 staining according to the manufacturer's recommendations (PhastGel Blue R, Pharmacia), the $\alpha_{1}$-AT bands were compared with the control samples corresponding to the PiM, PiMS, PiMZ or PiZZ and the phenotypes were examined. $\alpha_{1}$-antitrypsin genotyping by polymerase chain reaction

Genomic deoxyribonucleic acid extraction. Genomic DNA was simultaneously purified from peripheral blood cells (Nucleon BACC 3; Amersham Pharmacia Biotech, Orsay, France) and from serum taken for 39 patients. In four of the patients DNA was only extracted from their serum. As described by LiN and FLoros [19], two genomic DNA extraction methods from small amounts of serum were tested. The present authors found better results with a modified proteinase $\mathrm{K} /$ sodium dodecyl sulphate (SDS) lysis method. A total of $250 \mu \mathrm{L}$ of serum was treated with proteinase $\mathrm{K}$ (1.7 $\mathrm{mg} \cdot \mathrm{mL}^{-1}$; Gibco BRL, Life Technologies, CergyPontoise, France) and 5\% SDS (Sigma Aldrich, SaintQuentin Fallavier, France) at $65^{\circ} \mathrm{C}$ for $1 \mathrm{~h}$. This solution was then heated at $95^{\circ} \mathrm{C}$ for $10 \mathrm{~min}$ to inactivate the proteinase $\mathrm{K}$. The lysate was then phenol extracted and ethanol precipitated. After a centrifugation at $16000 \times \mathrm{g}, 4^{\circ} \mathrm{C}$ for $15 \mathrm{~min}$, the DNA pellet was dissolved in $25 \mu \mathrm{L}$ of Tris-HCL $10 \mathrm{mM}$ pH 8.5.

Polymerase chain reaction. The procedure for mutation analysis was modified from the PCR-mediated site-directed mutagenesis method of TAZELAAR et al. [22]. All amplifications were started in a $50 \mu \mathrm{L}$ reaction volume containing $50 \mu \mathrm{M}$ deoxynucleotide triphosphate (Sigma Aldrich, Saint-Quentin Fallavier, France), $2 \mathrm{mM} \mathrm{MgCl} 2$ (Gibco BRL, Life Technologies), $12.5 \mathrm{pM}$ of each primer (synthesised by the Common Molecular Biology Department of the Universitary Hospital of Nancy), $250 \mathrm{ng}$ of DNA, 1.25 U of Taq polymerase (Gibco BRL, Life Technologies). After an initial denaturation step at $94^{\circ} \mathrm{C}$ for $2 \mathrm{~min}$, a first amplification was carried out for 30 cycles, each cycle consisted of a 30 s denaturation time at $94^{\circ} \mathrm{C}$, a $30 \mathrm{~s}$ annealing time at $64^{\circ} \mathrm{C}$ and a $60 \mathrm{~s}$ extension time at $72^{\circ} \mathrm{C}$, followed by a final step at $72^{\circ} \mathrm{C}$ for 7 min on a Perkin-Elmer thermal cycler (Perkin Elmer, Norwalk, CT, USA). If this first amplification was not sufficient to obtain PCR products, a second identical 20-cycle PCR program was then performed to optimise the results.

Restriction enzyme digestion and electrophoresis. PCR products were first run on a $2 \%$ agarose gel in $89 \mathrm{mM}$ Tris-borate buffer containing $1 \mathrm{mM}$ ethylenediamine tetraacetic acid, $\mathrm{pH} 8.3$ at constant voltage of $130 \mathrm{~V}$ for $50 \mathrm{~min}$. A restriction digestion mixture was then prepared as follows: $10 \mu \mathrm{L}$ of PCR product was added to $40 \mathrm{U}$ of $\mathrm{Taq}$ I restriction endonuclease (Ozyme, Saint-Quentin, Yvelines, France) and to bovine serum albumin (BSA) and endonuclease buffer, to a final volume of $20 \mu \mathrm{L}$. The digestion mixture was incubated at $65^{\circ} \mathrm{C}$ for $2 \mathrm{~h}$, according to the manufacturer's recommendations (Ozyme). Finally, the digested PCR products were analysed on a $15 \%$ polyacrylamide gel after an electrophoresis performed in the same running buffer as described above at a constant voltage of $150 \mathrm{~V}$ for $90 \mathrm{~min}$ in accordance with the conclusions of TAZELAAR et al. [22]. 
1

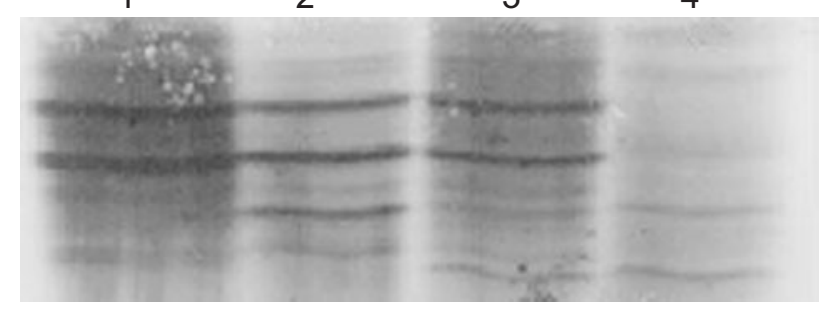

Fig. 1. - Isoelectric focusing gel of $\alpha_{1}$-antitrypsin ( $\mathrm{pH}$ range 4.2 4.9) obtained from serum samples. The anode is at the top. MM homozygote (lane 1), MS heterozygote (lane 2), MZ heterozygote (lane 3) and ZZ homozygote (lane 4).

\section{Results}

The blood samples for 43 patients between MarchDecember 2001 were obtained (18 females and 25 males, mean age was $52.2 \mathrm{yrs}$ ). A total of 37 serum $\alpha_{1}$-AT concentrations were considered as normal or increased and four were diminished, considering the reference values used $\left(91-182 \mathrm{mg} \cdot \mathrm{dL}^{-1}\right)$. Only six serum $\alpha_{1}$-AT concentrations were found $<91 \mathrm{mg} \cdot \mathrm{dL}^{-1}$.

The identification of the $\alpha_{1}$-AT phenotype was obtained by IEF for all of these patients: 29 were MM homozygotes, seven were heterozygotes for S, i.e. MS and four patients were MZ heterozygotes (fig. 1). As expected, three patients were ZZ homozygotes (fig. 1). The 6 patients whose serum $\alpha 1$-AT concentration was lower showed respectively $\mathrm{MZ}(\mathrm{n}=3)$ and $\mathrm{ZZ}(\mathrm{n}=3)$ phenotypes (fig. 1, table 1). These three $\mathrm{ZZ}$ patients

Table 1. $-\alpha_{1}$-antitrypsin serum concentration in the different phenotypic groups

\begin{tabular}{lcccc}
\hline & \multicolumn{4}{c}{ Phenotype } \\
\cline { 2 - 5 } & MM & MS & MZ & ZZ \\
\hline $\begin{array}{l}\text { Patients (n) } \\
\begin{array}{l}\alpha 1-A T \text { serum concentration } \\
\text { Mean } \pm \text { SD } \\
\text { Range }\end{array}\end{array}$ & 29 & 27 & 4 & 3 \\
\hline
\end{tabular}

Data are presented as $\mathrm{mg} \cdot \mathrm{dL}^{-1}$ were already known to suffer from a pulmonary emphysema.

The genotypic analysis was systematically performed with genomic DNA extracted from blood cells and with genomic DNA extracted from serum to validate the protocol for 39 patients. In four patients, genotype was only analysed from DNA extracted from serum.

As described by TazelaAR et al. [22], PCR primers were used to create $T a q$ I restriction sites that distinguished between normal and mutant DNA. The primers used to amplify the sequence that included the $\mathrm{Z}$ mutation site yielded a product of the correct size (179 bp) in seven cases. Subsequent digestion with Taq I gave results in agreement with those obtained by IEF (fig. 2): four patients were heterozygotes (MZ) and 3 patients were homozygotes for $Z$ allele. Similarly, the amplification product that included the $S$ mutation $(121 \mathrm{bp})$ was found in seven cases. All of these patients were heterozygotes (MS).

Serum extracted DNA gave identical results compared with those obtained with whole blood DNA for the 39 patients. The 43 genotyping results were all in agreement with the phenotyping results (fig. 1 and 2).

\section{Discussion}

The Pi allele was determined by PCR on DNA extracted from serum in 43 hospitalised patients. It was found by the authors that this procedure yielded good quality DNA equal to that extracted from whole blood, whatever the Pi allele.

DNA circulates freely in blood plasma both in disease and in health but the source of this serum DNA is not completely known [24]. In healthy subjects, it is assumed that circulating DNA is derived from lymphocytes or other nucleated cells. Cancer patients have a greater amount of circulating DNA than healthy subjects $[25,26]$. It seems unlikely that this tumoral DNA originates from the lysis of circulating cancer cells because the number of circulating cells usually found in plasma is not high enough to explain the large amount of DNA detected [27]. The role of tumoral necrosis is unclear since DNA plasma levels in cancer patients decreased up to $90 \%$ after radiation

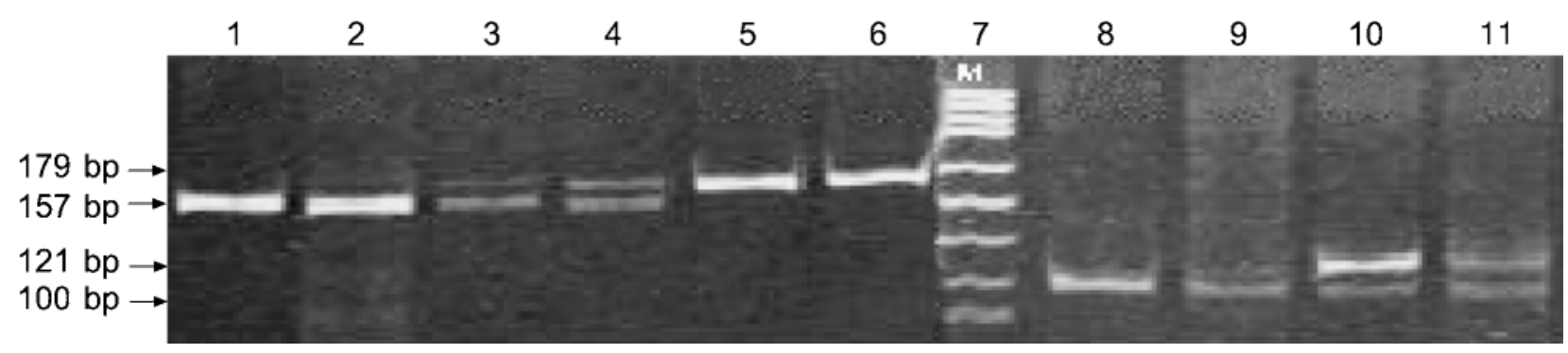

Fig. 2.-Ethidium bromide stained $15 \%$ polyacrylamide gel showing results of amplification and digestion of normal and mutant $\alpha_{1}$-antitrypsin alleles with Taq I restriction enzyme. The genotyping results were in agreement with phenotyping results. Lane 1: MM homozygote deoxyribonucleic acid (DNA) extracted from blood cells; lane 2: MM homozygote DNA extracted from serum; lane 3: MZ heterozygote DNA extracted from blood cells; lane 4: MZ heterozygote DNA extracted from serum; lane 5: ZZ homozygote DNA extracted from blood cells; lane 6: ZZ homozygote DNA extracted from serum; lane 7: size standard (Puc18; Sigma Aldrich, SaintQuentin Fallavier, France); lane 8: MM homozygote DNA extracted from blood cells; lane 9: MM homozygote DNA extracted from serum; lane 10: MS heterozygote DNA extracted from blood cells; and lane 11: MS heterozygote DNA extracted from serum. 
therapy, whereas an increase would be expected if necrosis is a major pathway of DNA release [25]. Apoptosis has been advanced as the origin of circulating DNA [26, 28, 29], however this mechanism is supposedly lost by proliferating cells. A fourth hypothesis is that the tumour actively releases DNA in blood by a mechanism similar to that observed in vitro when lymphocytes or whole organs spontaneously release DNA without any cell death [30].

In this study Pi genotyping was compared between DNA extracted from whole blood and DNA extracted from serum. In all cases, the two extraction procedures gave identical $\mathrm{Pi}$ genotypes and the results were in accordance with the phenotypic determination by isoelectric focusing. The present authors confirmed that genomic DNA prepared from small amounts of serum could serve as a template to amplify DNA segments in order to detect genetic alterations, as described by LIN and FLoros [19]. The combination of a micro-extraction procedure from serum and PCR genotyping provide a rapid and costless tool in genetic analysis [19]. A small amount of serum $(250 \mu \mathrm{L})$ can be very informative, since it yields enough DNA to analyse several genetic markers.

It is generally agreed that PCR methods are useful for the determination of the $\alpha_{1}$-AT deficiency variants PiS and PiZ [12]. Recently, Costa et al. [31] have proposed the use of dried blood spot specimens in quantitative $\alpha_{1}$-AT detection. Deficiency of $\alpha_{1}$-AT was evaluated by combining the results of $\alpha_{1}$-AT quantification and phenotyping. In cases in which there was discordance between $\alpha_{1}$-AT concentration and phenotype, diagnosis of hereditary $\alpha_{1}$-AT deficiency was established by $\alpha_{1}$-AT genotyping. In the study by CostA et al. [31], $\alpha_{1}$-AT genotype determination was carried out using DNA from dried blood spot specimens and fresh blood samples from four patients with different phenotypes ( $\mathrm{Pi} \mathrm{M}, \mathrm{MZ}, \mathrm{MS}$ and $\mathrm{Z}$ ). Identical genotypes were observed with PCR products obtained from dried blood spot specimens or from fresh blood [31].

The present study shows for the first time, to the best of the authors' knowledge, that amplified polymerase chain reaction products can be obtained from serum with the same quality as those obtained from whole blood, when used for $\alpha_{1}$-antitrypsin genotype analysis. Whilst further studies are needed to confirm these findings, the initial results are very encouraging. This deoxyribonucleic acid-based method is rapid, convenient, easier to perform and less laborious than the isoelectric focusing technique. The authors believe that genomic deoxyribonucleic acid extraction from small amounts of serum appears to be an alternative to deoxyribonucleic acid extracted from peripheral blood cells. Moreover, it will be a good complement of the isoelectric focusing technique, even though it is unlikely that it will completely replace it, due to the high number of variants that could be detected by this classical method. Also, this deoxyribonucleic acidbased method, allowing genomic deoxyribonucleic acid to be obtained from serum, can be used in genetic analysis with multiple genetic markers others than the $\alpha_{1}$-antiprotease inhibitor allele. It should open up possibilities for the analysis of existing specimens, and prove to be useful since serum libraries are more often available in laboratories than deoxyribonucleic acid ones.

Acknowledgements. The authors would like
to thank R. Debard and M. Valentin for their
excellent technical assistance.

\section{References}

1. Cox DW. $\alpha 1$-antitrypsin deficiency. In: Scriver CR, Beaudet AL, Sly WS, Valle D, eds. The metabolic and molecular bases of inherited disease. 7th Edn. New York, McGraw Hill, 1995; pp. 4125-4158.

2. Brantly M, Nukiwa T, Crystal RG. Molecular basis of a1-antitrypsin deficiency. Am J Med 1988; 84: 13-31.

3. Hutchinson DC. Alpha 1-antitrypsin deficiency in Europe: geographical distribution of Pi types $\mathrm{S}$ and $\mathrm{Z}$. Respir Med 1998; 92: 367-377.

4. Blanco I, Fernandez E, Bustillo EF. Alpha 1-antitrypsin PI phenotypes $\mathrm{S}$ and $\mathrm{Z}$ in Europe: an analysis of the published surveys. Clin Genet 2001; 60: 31-41.

5. Blanco I, Bustillo EF, Rodriguez MC. Distribution of $\alpha 1$-antitrypsin PI S and PI Z frequencies in countries outside Europe: a meta-analysis. Clin Genet 2001; 60: 431-441.

6. Carrell RW, Jeppsson JO, Laurell CB, et al. Structure and variation of human $\alpha 1$-antitrypsin. Nature 1982; 298: 329-334.

7. Allen RC, Harley RA, Talamo RC. A new method for determination of $\alpha 1-\mathrm{AT}$ phenotypes using isoelectric focusing on polyacrylamide gel slabs. Am J Clin Pathol, 1974; 62: 732-739.

8. Carrell RW, Lomas DA. Alpha 1-antitrypsin deficiency. A model for conformational diseases. $N$ Engl J Med, 2002; 346: 45-53.

9. Phelps RG, Shoji T. Update in panniculitis. The Mount Sinai Journal of Medicine 2001; 68: 262-267.

10. Long GL, Chandra T, Woo SL, Davie EW, Kurachi K. Complete sequence of the cDNA for human alpha 1-antitrypsin and the gene for the $\mathrm{S}$ variant. Biochemistry 1984; 23: 4828-4837.

11. Jeppsson JO. Amino acid substitution Glu leads to Lys alpha 1-antitrypsin PiZ. FEBS Lett 1976; 65: 195197.

12. Rieger S, Riemer H, Mannhalter C. Multiplex PCR assay for the detection of genetic variants of $\alpha 1-$ antitrypsin. Clin Chem 1999; 45: 688-690.

13. Von Ahsen N, Oellerich M, Schutz E. Use of two reporter dyes without interference in a single-tube rapid-cycle PCR: alpha 1-antitrypsin genotyping by multiplex real-time fluorescence PCR with the lightcycler. Clin Chem 2000; 46: 156-161.

14. Dry PJ. Rapid detection of alpha 1-antitrypsin deficiency by analysis of a PCR-induced Taq I restriction site. Hum Genet 1991; 87: 742-744.

15. Lam CWK, Pang CP, Poon PMK, Yin CH, Bharathi G. Rapid screening for alpha 1-antitrypsin $\mathrm{Z}$ and $\mathrm{S}$ mutations. Clin Chem 1997; 43: 403-404.

16. Mandel P, Metais P. Les acides nucleiques du plasma sanguin chez I'homme [Nucleic acids in human plasma]. C.R. Acad Sci Paris 1948; 142: 241-243.

17. Stroun M, Maurice $\mathrm{P}$, Vasioukhin $\mathrm{V}$, et al. The origin and mechanism of circulating DNA. In: Anker P, 
Stroun M, eds. Circulating nucleic acids in plasma or serum. New York, Annals of New York Academy of Sciences, 2000; 906: pp. 161-168.

18. Sanford AJ, Pare PD. Direct PCR of small genomic DNA fragments from serum. Biotechniques 1997; 23: 890-892.

19. Lin Z, Floros J. Genomic DNA extraction from small amounts of sera to be used for genotype analyses. Biotechniques 1998; 24: 937-940.

20. Lin Z, Floros J. Protocole for genomic DNA preparation from fresh or frozen serum for PCR amplification. Biotechniques 2000; 29: 461-466.

21. Jen J, Wu L, Sidransky D. An overview on the isolation and analysis of circulating tumor DNA in plasma and serum. In: Anker P, Stroun M, eds. Circulating nucleic acids in plasma or serum. New York, Annals of New York Academy of Sciences, 2000; 906: pp. 8-12.

22. Tazelaar JP, Friedman KJ, Kline RS, Guthrie ML, Farber RA. Detection of $\alpha 1$-antitrypsin $Z$ and $S$ mutations by polymerase chain reaction-mediated site-directed mutagenesis. Clin Chem 1992; 38: 14861488.

23. Jeppsson JO, Franzen B. Typing of genetic variants of al-antitrypsin by electrofocusing. Clin Chem 1982; 28: 219-225.

24. Anker P. Quantitative aspects of plasma/serum DNA in cancer patients. In: Anker $\mathrm{P}$, Stroun $\mathrm{M}$, eds. Circulating nucleic acids in plasma or serum. New York, Annals of New York Academy of Sciences 2000; 906: pp. 5-7.
25. Leon SA, Shapiro DM, Sklaroff DM, Yaros MJ. Free DNA in the serum of cancer patients and the effect of therapy. Cancer Res 1977; 37: 646-650.

26. Fournie GJ, Courtin JP, Laval F. Plasma DNA as a marker of cancerous cell death: investigation in patients suffering from lung cancer and in nude mice bearing human tumour. Cancer Lett 1995; 2: 221-227.

27. Sorenson GD, Porter DM, Barth RJ, et al. Detection of mutated KRAS2 sequences in plasma from patients with pancreatic carcinoma in comparison with the Ca19-9 assay. J Int Soc Oncodev Biol Med 1997; 18: 66.

28. Stroun M, Anker J, Lyautey C, Lederrey C, Maurice PA. Isolation and characterization of DNA from the plasma of cancer patients. Eur J Cancer Clin Oncol 1987; 23: 707-712.

29. Giacona MB, Ruben GC, Iczkowski KA, Roos TB, Porter DM, Sorenson GD. Cell-free DNA in human blood plasma: length measurements in patients with pancreatic cancer and healthy controls. Pancreas 1998; 17: 89-97.

30. Sidransky D. Circulating DNA. What we know and what we need to learn. In: Anker P, Stroun M, eds. Circulating nucleic acids in plasma or serum. New York, Annals of New York Academy of Sciences, 2000; 906: pp. 1-4.

31. Costa X, Jardi R, Rodriguez F, et al. Simple method for $\alpha 1$-antitrypsin deficiency screening by use of dried blood spot specimens. Eur Respir $J$ 2000; 15: 1111-1115. 